\title{
Influence of environmental variability and age on the body condition of small pelagic fish in the Gulf of Lions
}

\author{
Pablo Brosset $^{1,2, *}$, Frédéric Ménard ${ }^{3}$, Jean-Marc Fromentin ${ }^{2}$, Sylvain Bonhommeau ${ }^{2}$, \\ Caroline Ulses $^{4}$, Jean-Hervé Bourdeix ${ }^{2}$, Jean-Louis Bigot ${ }^{2}$, Elisabeth Van Beveren ${ }^{2}$, \\ David $\operatorname{Roos}^{2}$, Claire Saraux ${ }^{2}$ \\ ${ }^{1}$ University of Montpellier, UMR MARBEC (IRD, Ifremer, UM, CNRS), 34203 Sète cedex, France \\ ${ }^{2}$ IFREMER, UMR MARBEC (IRD, Ifremer, UM, CNRS), 34203 Sète cedex, France \\ ${ }^{3}$ IRD, Mediterranean Institute of Oceanography (MIO), Aix-Marseille Université/CNRS/IRD/Université de Toulon, UM 110, \\ 13288 Marseille, France \\ ${ }^{4}$ University of Toulouse 3, CNRS/INSU, Laboratoire d'Aérologie UMR 5560, 14 Avenue Edouard Belin, 31400 Toulouse, \\ France
}

\begin{abstract}
Endogenous and environmental variables are fundamental in explaining variations in fish condition. Based on more than $20 \mathrm{yr}$ of fish weight and length data, relative condition indices were computed for anchovy and sardine caught in the Gulf of Lions. Classification and regression trees (CART) were used to identify endogenous factors affecting fish condition, and to group years of similar condition. Both species showed a similar annual cycle with condition being minimal in February and maximal in July. CART identified 3 groups of years where the fish populations generally showed poor, average and good condition and within which condition differed between age classes but not according to sex. In particular, during the period of poor condition (mostly recent years), sardines older than $1 \mathrm{yr}$ appeared to be more strongly affected than younger individuals. Time-series were analyzed using generalized linear models (GLMs) to examine the effects of oceanographic abiotic (temperature, Western Mediterranean Oscillation [WeMO] and Rhône outflow) and biotic (chlorophyll $a$ and 6 plankton classes) factors on fish condition. The selected models explained 48 and $35 \%$ of the variance of anchovy and sardine condition, respectively. Sardine condition was negatively related to temperature but positively related to the WeMO and mesozooplankton and diatom concentrations. A positive effect of mesozooplankton and Rhône runoff on anchovy condition was detected. The importance of increasing temperatures and reduced water mixing in the NW Mediterranean Sea, affecting planktonic productivity and thus fish condition by bottom-up control processes, was highlighted by these results. Changes in plankton quality, quantity and phenology could lead to insufficient or inadequate food supply for both species.
\end{abstract}

KEY WORDS: Anchovy - Sardine - Relative condition factor - NW Mediterranean Sea · Endogenous effect $\cdot$ Environmental effect

Resale or republication not permitted without written consent of the publisher

\section{INTRODUCTION}

Body condition is widely used in ecological studies to determine the nutritional or physiological status of an individual (Bolger \& Connolly 1989, Stevenson \& Woods 2006) and is defined as the quantity of nutrient reserves, i.e. the quantity of accumulated energy reserves exceeding that required for daily nutritional demands (Schulte-Hostedde et al. 2001, Schamber et al. 2009). Body condition indices are thus used in order to evaluate the quantity of stored energy, giving an indication of an individual's well-being which can 
affect its future performances (Stevenson \& Woods 2006, Wilson \& Nussey 2010). For example, individuals with larger nutritional reserves may have a higher probability of survival and reproductive success or growth (Millar \& Hickling 1990), which may in turn affect the dynamics of the whole population (Jakob et al. 1996, Adams 1999). Many studies have used fish condition indices to monitor and investigate both pelagic and demersal fish population health and variability (Lambert \& Dutil 1997, Lloret et al. 2002, Shulman et al. 2005, Ndjaula et al. 2013). Anomalous conditions have been shown to strongly affect spawning and egg quality and quantity in many fish species (Adams 1999, Óskarsson et al. 2002). Earlier sexual maturation, associated with smaller size as well as higher natural mortality, has also been shown to occur in Atlantic herring Clupea harengus in poor condition (Winters \& Wheeler 1994, Heino \& Godø 2002, Malzahn et al. 2007), while the chances of becoming mature increase with good condition in American plaice Hippoglossoides platessoides (Morgan 2004).

Fish condition may be linked to several factors that can be either endogenous or exogenous (Shulman \& Love 1999, Lloret et al. 2014). Reproductive state, sex or age are the main endogenous parameters known to affect condition. Drastic changes in population age/size structure have resulted from differences between individuals of a single species. For example, an improvement in condition in females and older individuals led to an unbalanced sex-ratio or age distribution and increased population vulnerability to environmental stress in Pagellus erythrinus (Lloret et al. 2002). Exogenous factors that can potentially impact body condition are numerous as well, ranging from parasitism (Lambert \& Dutil 1997, Barton et al. 2002, Ferrer-Maza et al. 2014, 2015) to environmental conditions or food availability (Murphy et al. 1990, Porath \& Peters 1997, Villegas-Hernández et al. 2015), which highlights the value of using fish body condition as a measure of habitat quality and exogenous disturbance.

Anchovy Engraulis encrasicolus and sardine Sardina pilchardus populations supported important fisheries in the Gulf of Lions before exhibiting a major decline in the 2000s, while the unexploited sprat Sprattus sprattus increased exponentially (GFCM 2012). The biomass of these small pelagic species and their role in energy transfer from low (e.g. plankton communities) to high (e.g. marine mammals, tunas, seabirds) trophic levels underscores their importance in the ecosystem (Cury et al. 2000, Bănaru et al. 2013). In the Gulf of Lions, while the biomass of anchovy and sardine decreased, the num- ber of sardines slightly increased and the number of anchovies remained steady due to the abundance of small and young individuals (Van Beveren et al. 2014). This indicates changes in the size and ageclass distribution of both species. In parallel, fish condition started to deteriorate before the mean length and age decreased in both species, suggesting that condition and nutritional status might be an important factor explaining currently observed population dynamics. Moreover, overexploitation was not ultimately retained as the driving force for this pelagic ecosystem shift; rather, bottom-up processes are the current major hypothesis for the change in small pelagic fish condition in this area (Van Beveren et al. 2014). Further investigation into the determinants of body condition are thus warranted to better understand the current situation of these stocks.

The aim of the present study was to more precisely analyze the variations in anchovy and sardine condition in the Gulf of Lions using a unique long-term dataset of morphometric (length and weight) and biological (age and sex) variables from more than 43000 individuals obtained from 1971-1978, and 1993-2013. The first objective was to confirm the existence of different groups of years based on fish condition for both species using the largest dataset available in the Gulf of Lions. Secondly, according to the previously defined groups of years of fish condition, we investigated the potential effect of sex and age on the condition of each species. Finally, we related the fluctuations in fish condition to environmental variables in order to determine potential exogenous drivers of the dynamics of small pelagic fish in the Gulf of Lions.

\section{MATERIALS AND METHODS}

\section{Study area and data collection}

This study took place in the Gulf of Lions, which encompasses approximately $10000 \mathrm{~km}^{2}$ of the northwestern part of the Mediterranean Sea $\left(42^{\circ} 26^{\prime} \mathrm{N}\right.$, $3^{\circ} 00^{\prime} \mathrm{E}$ to $43^{\circ} 40^{\prime} \mathrm{N}, 5^{\circ} 28^{\prime} \mathrm{E}$ ). This area is characterized by a wide continental margin $(>60 \mathrm{~km})$, bordered by numerous canyons (Millot 1990). The Gulf of Lions is one of the most productive regions in the Mediterranean as a result of Rhodanian inputs and strong mixing events induced by northwest and north winds, as well as local upwellings (Palomera et al. 2007). A nutrient gradient exists from east to west due to the Rhodanian input in the eastern portion of the region (Darnaude et al. 2004). 
Samples were collected from both scientific and commercial pelagic trawls. PELMED (PELagiques en MEDiterranée) scientific surveys have been conducted each July from 1993 to 2013 onboard the R/V 'l'Europe', using acoustic methods to assess small pelagic fish biomass. Each year, 9 parallel fixed transects running perpendicular to the coastline were surveyed. Acoustic data allowed the detection of fish occurrence, and pelagic trawls were deployed to determine fish school composition when these acoustic records were long enough (>2 nm). A random sample of fish in each trawl was collected, and the morphometric parameters of size (to the nearest $\mathrm{mm}$ ) and body mass (to the nearest $0.1 \mathrm{~g}$ ), as well as age (reading otoliths), sex (by visual assessment) and maturity stage (by visual assessment according to ICES 2008) were determined for each fish. Maturity was described as a stage from 1 to 6, with increasing development of gonads in Stages 2 to 4 , spawning period during Stage 5 and resting period during Stages 6 and 1. To investigate the seasonality of fish condition, samples were collected from other times of the year from commercial fisheries, and brought back to the lab for analyses. These samples were collected randomly in the Gulf of Lions between 1999 and 2013 (more regularly since 2005) during different months of the year (except July, which was covered by the scientific survey). Samples consisted of one crate of fish randomly taken out of a pelagic trawl before any sorting had occurred. Once in the lab, the same parameters as previously described for the scientific survey were measured. Data for sardine between 1971 and 1978 were also collected monthly by the commercial fleet and analyzed in the lab with the same accuracy. Thus, both periods (i.e. 1971 to 1978 and 1993 to 2013) were judged comparable. In all fish sampling, the length range was kept as large as possible to allow subsequent comparisons between periods and avoid any bias in the calculation of length-weight relationships.

\section{Morphometric index of condition}

As recommended by Froese (2006) when comparing condition within a given sample, and since the 2 studied species exhibited an allometric growth pattern (Van Beveren et al. 2014), we used the relative condition index $K_{\mathrm{n}}$ (Le Cren 1951, Bolger \& Connolly 1989, Blackwell et al. 2000):

$$
K_{\mathrm{n}}=W / W_{\mathrm{r}}
$$

where $W_{\mathrm{r}}=\alpha \mathrm{TL}^{\beta}$, the predicted weight of an individual of a given total length, TL. Length-weight rela- tionships were calculated separately for each month of each year (when the number of individuals was $>10$ ), and the parameters $\alpha_{\mathrm{m}}$ and $\beta_{\mathrm{m}}$ were then computed as the geometric mean of all the $\alpha$ and $\beta$ values obtained. As no difference in the length-weight relationship was found between sex or between juveniles versus adults (tested as an interaction with fish length in separate linear models, e.g. $\ln W \sim \ln L T \times$ Sex for sex effect), no distinction was made between males, females, juveniles and adults, and a single length-weight relationship was computed. Based on the 30 yr dataset which included more than 43000 individuals (Table 1), the following values were obtained: $\alpha_{\mathrm{m}}=3.7 \times 10^{-3} \pm 2.1 \times 10^{-4} ; \beta_{\mathrm{m}}=3.3 \pm 2.3 \times$ $10^{-2}$ for anchovy, and $\alpha_{\mathrm{m}}=9.1 \times 10^{-3} \pm 9.2 \times 10^{-4} ; \beta_{\mathrm{m}}=$ $3.1 \pm 4.2 \times 10^{-2}$ for sardine. Fitted $\beta$ values were in the usual range of 2.5 to 4 (Mendes et al. 2004, Froese 2006, Sinovčić et al. 2008).

The relative condition index is centered on 1, with higher and lower values indicating good or poor condition, respectively. Note that once standardized, the relative condition index is centered on 0 , as used in Figs. 2, $3 \& 4$. As recommended by several authors (Schulte-Hostedde et al. 2005, Stevenson \& Woods 2006, McPherson et al. 2011), this morphometric index was comparable with direct assessment of total lipid content outside the reproductive period (Brosset et al. 2015). During the reproductive period, Brosset et al. (2015) found that this index could reflect a more integrative measure of condition (such as lipids and proteins).

\section{Environmental parameters in the Gulf of Lions}

Small pelagic populations are subject to considerable fluctuations caused by environmental variability (Bakun 1996), mainly due to their relatively short life span (3 to 5 yr). Satellite-derived sea surface temperature $\left(\mathrm{SST}_{;}{ }^{\circ} \mathrm{C}\right)$ and surface chlorophyll a (chl $a_{;} \mathrm{mg}$ $\mathrm{m}^{-3}$ ) were extracted from MODIS-aqua data (http:// oceancolor.gsfc.nasa.gov). The Rhône outflow $\left(\mathrm{m}^{3}\right.$ $\mathrm{s}^{-1}$ ) was computed using the daily inputs of the Grand Rhône measured at the Beaucaire station, provided by the Compagnie Nationale du Rhône (CNR). The Western Mediterranean Oscillation index (WeMO; Martin-Vide \& Lopez-Bustins 2006) was computed as the daily differences in standardized surface atmospheric pressure values between San Fernando (Spain) and Padua (Italy) (J. A. López-Bustins pers. comm). This index integrates fluctuations in temperature, rainfall and wind mixing. Positive values reflect low temperatures and high river runoff and 
Table 1. Dataset characteristics for sardine and anchovy used in the study. Number of individuals and size range (total length in mm; shown in parenthesis) are provided for each month of the different groups of years identified

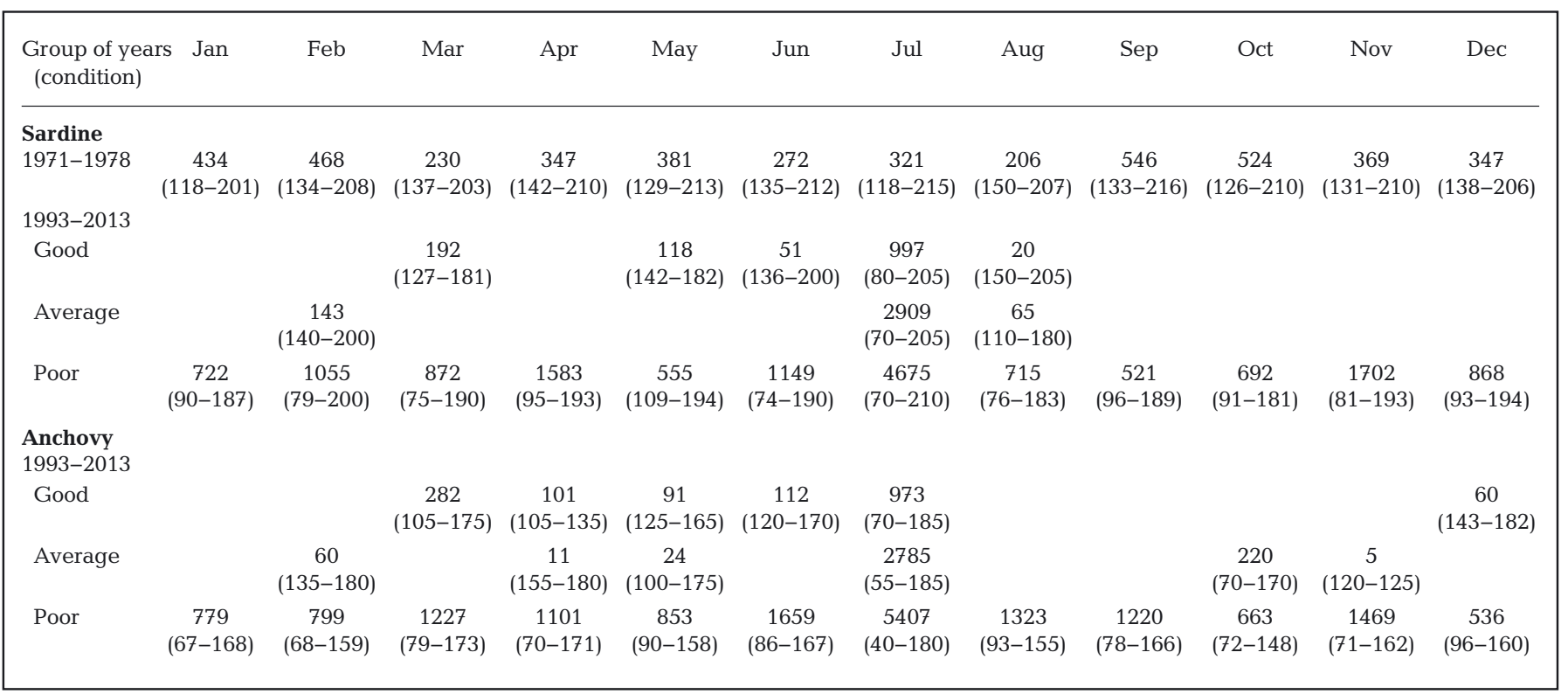

wind mixing, while negative values reflect the opposite. As environmental variability also affects primary and secondary production, the planktonic community was included in our analyses. Daily plankton concentration estimates were extracted from the coupled physical-biogeochemical model SYMPHONIE-Eco3m-S. The physical model, SYMPHONIE (Marsaleix et al. 2009, 2011, 2012), is based on a 3-dimensional primitive equation, free surface model, with hydrostatic and Boussinesq approximations. The biogeochemical model, Eco3m-S (Baklouti et al. 2006a,b, Auger et al. 2011), is a multi-nutrient and multi-plankton functional type model that simulates the dynamics of several biogeochemical elements (carbon, nitrogen, phosphorus, silica and chlorophyll) and plankton groups: picophytoplankton $(0.7$ to $2 \mu \mathrm{m}$ ); nanophytoplankton (2 to $20 \mu \mathrm{m}$, with high taxonomic heterogeneity); microphytoplankton (20 to $200 \mu \mathrm{m}$, dominated by diatoms); nanozooplankton (5 to $20 \mu \mathrm{m}$, comprised of small ciliates, flagellates and bacteriophages); microzooplankton (20 to $200 \mu \mathrm{m}$, ciliates and large flagellates); and mesozooplankton ( $>200 \mu \mathrm{m}$, mainly copepod species). The coupled model was previously used to study the dynamics of plankton communities impacted by freshwater discharge and their role in carbon export in the Gulf of Lions (Auger et al. 2011), as well as the interannual biogeochemical variability linked to atmospheric and hydrodynamic forcing in the Gulf of Lions from climatological (Herrmann et al. 2013) and statistical (Auger et al. 2014) points of view. In this study, we used a horizontal curvilinear mesh, giving a resolution $<1 \mathrm{~km}$ on the Catalan and western Gulf of Lions shelf and $\sim 2 \mathrm{~km}$ near the eastern coast of the Gulf of Lions. Initialization and boundary conditions were provided by the NEMOMED8 model (Herrmann et al. 2010). The coupled model was forced by the atmospheric ARPERA model outputs (Herrmann \& Somot 2008). MODIS chl a monitoring started in 2002, and the biogeochemical simulation that provided 6 classes of

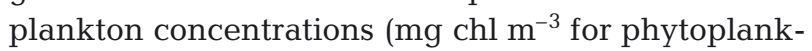

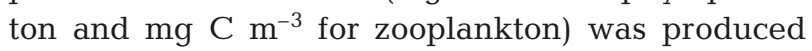
over the period of 2001 to 2011. Therefore, we extracted morphometric data for the Gulf of Lions from January 2002 to December 2011, with the advantage that this decade covered good, average and poor condition years for both anchovy and sardine in the Gulf of Lions. The variables were averaged for each month from January 2002 to December 2011 over the entire Gulf of Lions.

\section{Data analyses}

Two components of the time-series dataset were studied in this paper. One was a description of the seasonal cycle of anchovy and sardine condition. The other linked fish condition and environmental drivers, allowing a greater understanding of fish condition fluctuations in the Gulf of Lions. Therefore, the time-series was decomposed into: 


$$
\text { Series }=\text { Trend }+ \text { Seasonality }+ \text { Residuals }
$$

First, we studied the seasonal signal of fish condition, which was computed for anchovy over the whole studied period (1993-2013). Due to a temporal gap of $14 \mathrm{yr}$ in the dataset (from 1979-1992), sardine data were divided into 2 periods (1971-1978 and 1993-2013). Seasonal cycles were then estimated by period and compared using a generalized linear model (GLM) including a period effect and the interaction between month and period.

The dataset contained irregularities in the sampling scheme (e.g. different monthly sample sizes, missing data for some months; Table 1). To avoid any influence of sampling month on the endogenous and exogenous factors possibly affecting fish condition, we de-seasonalized and scaled the fish condition data. De-seasonalized values were obtained by removing median values estimated with the seasonal cycle of condition for each species. All values were then scaled by dividing each value by the standard deviation (SD) of the corresponding month. To investigate the potential effects of endogenous factors (sex and age), we then used the classification and regression tree (CART) approach of Breiman et al. (1984). Decision trees were built by recursively partitioning the dataset into increasingly homogeneous subgroups based on fish condition values. Each split was defined by a simple rule based on a single explanatory variable, and each final group was characterized by mean values of fish condition. Two separate CARTs were applied for the 2 species. Year was also added as an explanatory categorical variable in order to precisely define groups of years according to fish condition.

In addition, we evaluated the link between environmental variables and fish condition over a decade using data available from January 2002 to December 2011. As we were interested in the origin of the trend in fish condition, we de-seasonalized environmental data to reduce risks of spurious correlation that could occur due to a seasonal cycle. Following the same procedure applied for fish condition, environmental variables were (1) de-seasonalized by removing median values of the raw data and (2) scaled by dividing by the SD. The standardized environmental time-series were implemented as explanatory variables in a GLM approach.

Because this paper concentrated on factors influencing fish condition, we did not consider interactions between the explanatory variables. Model residuals were visually assessed for normality, and an untransformed response with a normal error structure was found to be appropriate. As the sample size (n) was small compared to the number of predictor variables $(P),(\mathrm{n} / P<40)$, Akaike's information criterion corrected for small sample sizes (AICc) was used to select the best model (Hurvich \& Tsai 1989). GLMs were used to detect the potential effects of environmental parameters on fish condition as follows:

$$
\begin{aligned}
K_{\mathrm{n}}= & \mu+\alpha \mathrm{SST}+\beta \mathrm{chl} a+\gamma \text { Rhône runoff }+\delta \text { WeMO } \\
& + \text { 殒oomeso }+\lambda \text { Zoomicro }+v \text { Zoonano } \\
& +\xi \text { Syn }+\omega \text { Diatom }+\rho \text { Nano }+\varepsilon
\end{aligned}
$$

where $\mu$ is the intercept $\beta, \gamma, \delta, \theta, \lambda, v, \xi$, $\omega$ and $\rho$ are the linear coefficients of the respective environmental parameters, and $\varepsilon$ is the error relative to a normal distribution.

Variance inflation factors (VIFs) were calculated between all environmental parameters to detect high-dimensional collinearity. When collinearity was identified, the covariates with the highest VIFs were sequentially removed from the model until the highest VIF value was $<5$ (Zuur et al. 2007). The same model was run for both anchovy and sardine.

All statistical analyses were performed with $\mathrm{R}$ v.3.0.2 (R Core Team 2013). Values are given as mean $\pm \mathrm{SE}$, and statistical tests were considered significant at $p<0.05$. Since autocorrelation has been recognized as inflating the probability of a Type I error in hypotheses tests, causing biases in variable selection and violating the assumption of independence of error terms in regression models, we also checked for temporal autocorrelation in both anchovy and sardine condition time-series; however, no autocorrelation was detected.

\section{RESULTS}

\section{Annual cycle of fish condition}

The period and the interaction between period and month were significant for sardine (GLMs; df $=1$, $\mathrm{p}<0.001$ and $\mathrm{df}=11, \mathrm{p}<0.001$, respectively), indicating changes in the phenology of the condition and the need to run separate analyses for each period. The relative condition index values $K_{\mathrm{n}}$ for each month (excluding April) were significantly higher during 1971-1978 (Fig. 1). Anchovy showed a minimal $K_{\mathrm{n}}$ in winter during January $(0.89 \pm 0.002)$ and February $(0.89 \pm 0.003)$, and a peak at the beginning of summer in June $(1.05 \pm 0.002)$ and July $(1.05 \pm$ 0.001). Sardine exhibited a similar pattern to that of anchovy for the minimum $(0.85 \pm 0.006)$ and maximum $(1.08 \pm 0.002) K_{\mathrm{n}}$ during 1993-2013, while maximum $K_{\mathrm{n}}$ occurred later (e.g. $1.15 \pm 0.005$ in Septem- 


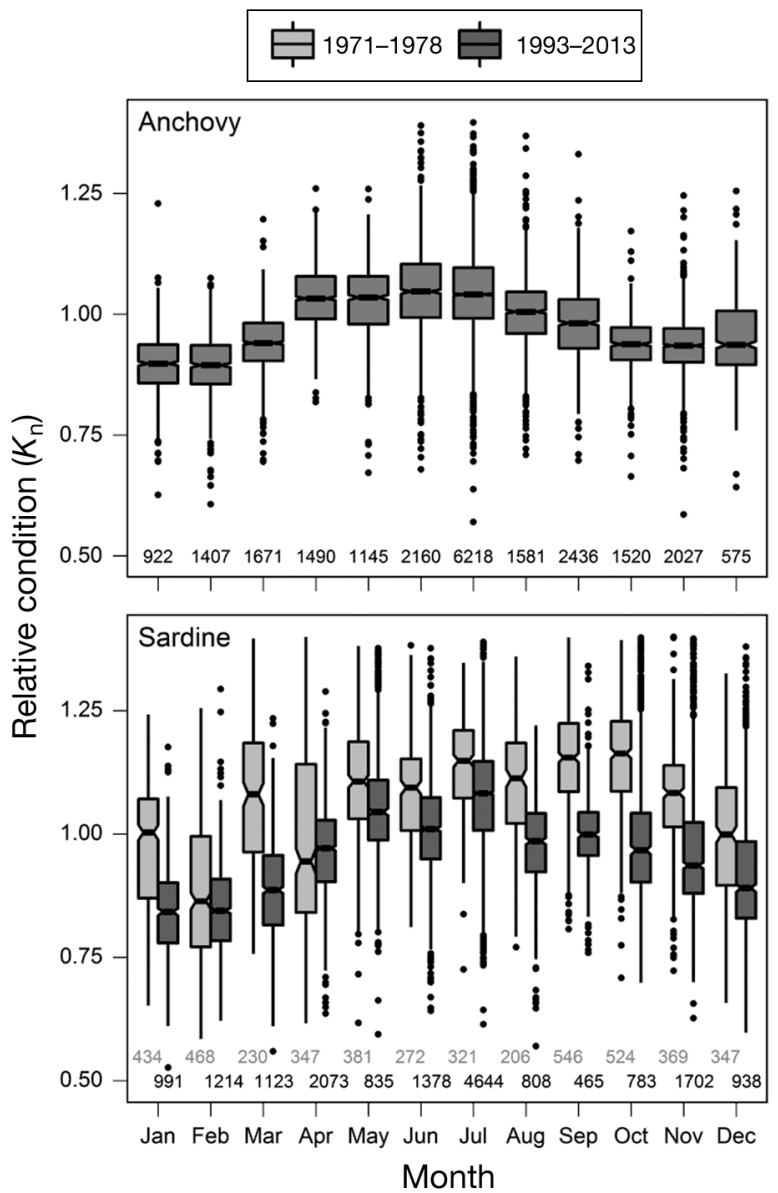

Fig. 1. Seasonal cycle of the relative condition for anchovy and sardine. The condition of sardines was significantly higher during 1971-1978 for all months (except April). The number of individuals sampled during each month is included at the bottom of the boxplot

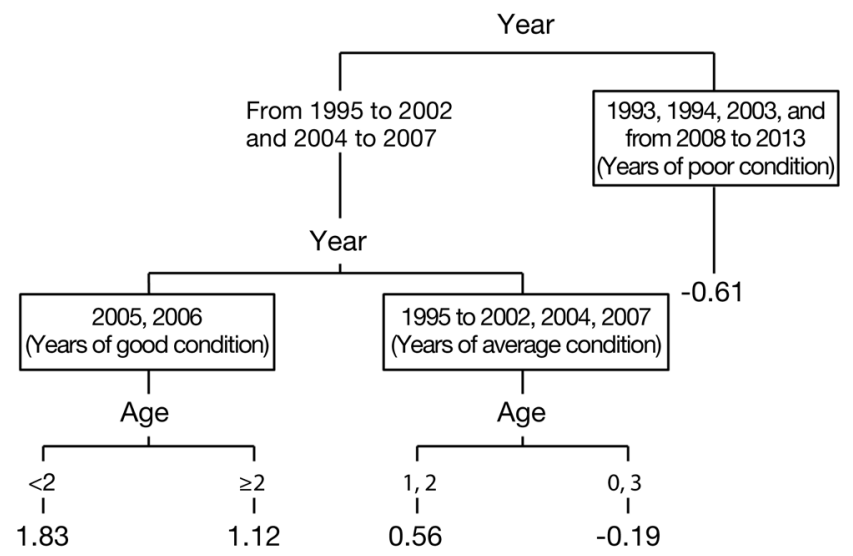

Fig. 2. Classification and regression tree assessing the importance of year, age and sex in anchovy condition values. The tree is split off on the values of one covariate at a time such that the overall variance in the dependent variable is minimized at each split. Terminal nodes indicate the value of anchovy standardized relative condition assigned to the node. The different groups of years identified according to anchovy condition are highlighted in the boxes

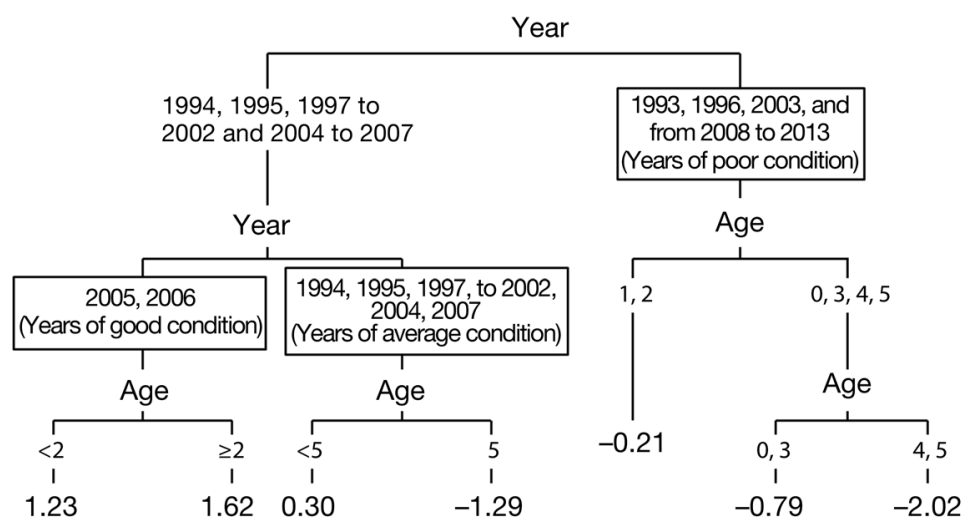

Fig. 3. Classification and regression tree assessing the importance of year, age and sex in sardine condition values. The tree is split off on the values of one covariate at a time such that the overall variance in the dependent variable is minimized at each split. Terminal nodes indicate the value of sardine standardized relative condition assigned to the node. The different groups of years identified according to sardine condition are highlighted in the boxes

ber and $1.16 \pm 0.005$ in October) during the earlier years (1971-1978).

\section{Fish condition partition and endogenous factors}

Regression trees (i.e. CART analyses) were used to partition fish condition data in relation to year, age and sex. They revealed year and age as explanatory variables for both species, whereas sex did not show any significant effects (Figs. $2 \& 3$ ). Year had the greatest effect on anchovy condition, with the highest $K_{\mathrm{n}}$ values for years from 1995 to 2007 (except 2003) (Fig. 2). In this group, a secondary partition separated the highest values (for years 2005 and 2006) from the others. Three groups of years were thus identified for anchovy (Fig. 2). Within these groups of years, condition was then partitioned according to age. While no effect of age was demonstrated in the poor condition years, anchovy condition tended to slightly deteriorate with age during the years of average and good condition (Figs. 2 \& 4).

Year was also the most important variable explaining sardine condition. Indeed, 3 groups of years were identified: years of poor condition (1993, 1996, 2003 and 2008 to 2013), years of good condition (2005 and 2006, as for anchovy) and years of average condition (1994, 1995, 1997 to 2002, 2004 and 2007) (Fig. 3). Age then determined the following nodes. In years of good condition, sardine condition improved from age 0 to $1 \mathrm{yr}$, and was better and steady in individuals $>2$ yr (Figs. $3 \& 4$ ). A similar pattern of sardine condi- 

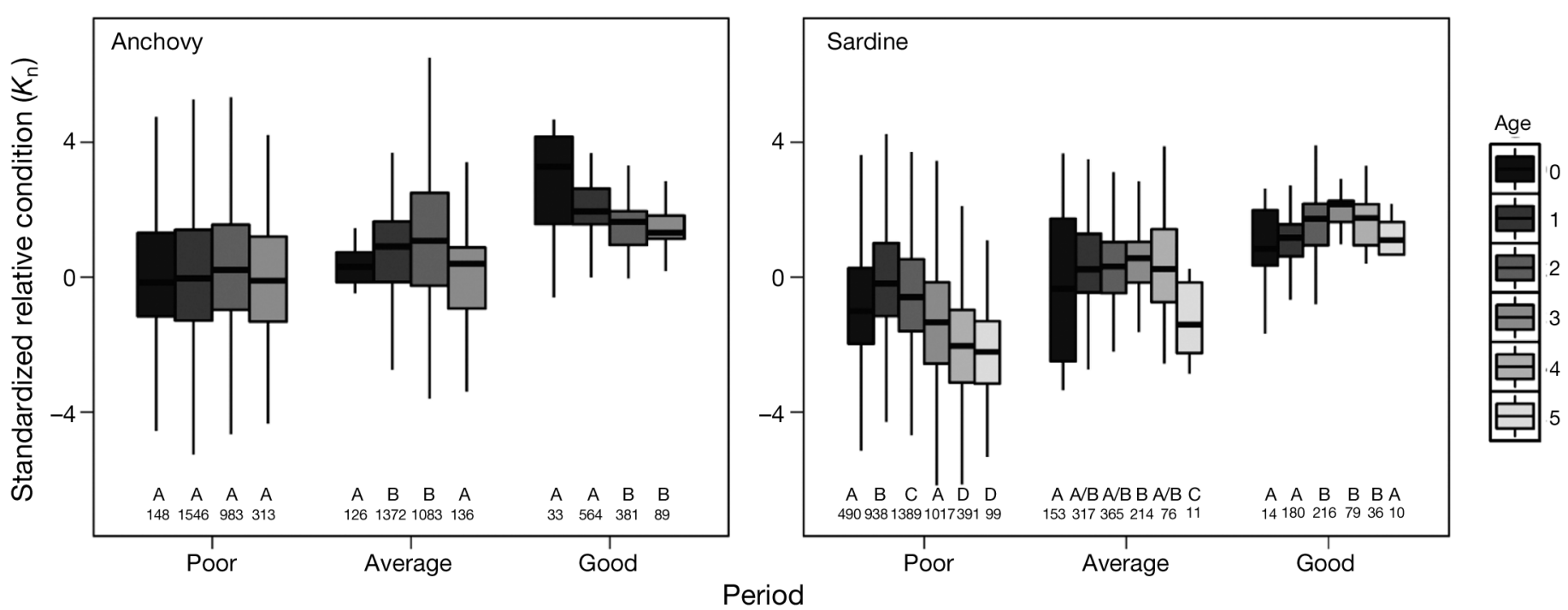

Fig. 4. Standardized relative condition as a function of age for anchovy and sardine. Number of individuals in each age class is included below each boxplot; letters indicate box age-classes that are statistically different for each group of years

tion with age was observed in years of average condition, even if it was not significant (except for individuals older than 5, which were in significantly poorer condition than the other age classes, though this was based on 11 individuals only) (Figs. 3 \& 4). In contrast, in years of poor condition (which comprised the last 6 yr), condition seemed to considerably deteriorate with increasing age after fish were 1 yr old. Sardine of age 3, 4 and 5 exhibited the worst conditions observed in the dataset (Fig. 4).

\section{Fish condition and environmental parameters}

VIFs were calculated to determine variables with high collinearity. As the picophytoplankton showed a value of 8.42 , this variable was removed from the model for each species. Other variables showed a maximum VIF of 4.58 and did not introduce a major bias into our analyses. The AICc selected models including mesozooplankton and Rhône runoff for anchovy, and mesozooplankton, temperature, WeMO and diatom concentration for sardine.

Anchovy condition was significantly and positively influenced by the concentration of mesozooplankton and the Rhône runoff (Table 2). For sardine, the GLM revealed a significant positive relationship of condition with mesozooplankton concentration, WeMO and diatom concentration, while there was a negative effect of temperature (Table 2). Final models selected with AICc explained 48 and $35 \%$ of the variance for anchovy and sardine $\left(\mathrm{r}^{2}{ }_{\mathrm{adj}}\right)$, respectively.

\section{DISCUSSION}

\section{Annual cycle of anchovy and sardine condition}

Monthly variations of fish condition showed similar patterns for anchovy and sardine. Condition was maximal in summer and minimal in winter, as has been described in other Mediterranean areas (Basilone et al. 2006, Zlatanos \& Laskaridis 2007, Simat \& Bogdanovi 2012) and in the Gulf of Lions through lipid analysis (Pethybridge et al. 2014). However, while sardine exhibited a strong difference in condition between winter and summer, seasonal variations in condition were smaller for anchovy. Such differences between species might be explained by different spawning strategies and the seasonality of prey abundance. Summer and winter represent periods of high versus low energy intake for both species due to increased food (Lefevre et al. 1997) determined by prey availability and quality in spring/summer. However, energy expediture differs greatly between the 2 species: anchovies are income breeders (i.e. they acquire energy concurrently to the spawning period), whereas sardines are capital breeders (i.e. they store energy before the spawning period; see Ganias et al. 2007, Pethybridge et al. 2014, McBride et al. 2015). At the beginning of spring, the condition of both species improves due to higher prey availability, but for anchovies a part of that energy storage is then allocated directly to the gonads for summer spawning. On the contrary, the energy storage of sardine continues to increase (and 
Table 2. Results of generalized linear models (GLMs) selected by Akaike's information criterion corrected for small sample sizes (AICc) for anchovy and sardine. The relative condition index was taken as a function of sea surface temperature (SST), chl a concentration, Rhône runoff, Western Mediterranean Oscillation (WeMO), mesozooplankton concentration (Mesozoo), nanozooplankton concentration (Nanozoo), microzooplankton concentrations (Microzoo), nanophytoplankton concentration (Nanophyto) and microphytoplankton concentration (Diat). All data were standardized and GLMs were performed with a Gaussian distribution and identity link

\begin{tabular}{|c|c|c|c|c|c|c|c|c|}
\hline \multirow{2}{*}{ Parameter } & \multicolumn{4}{|c|}{ - Anchovy } & \multicolumn{4}{|c|}{ Sardine- } \\
\hline & Estimate & SE & $t$ & $\mathrm{p}$ & Estimate & $\mathrm{SE}$ & $t$ & $\mathrm{p}$ \\
\hline Intercept & 0.168 & 0.146 & 1.179 & 0.235 & -1.215 & 0.388 & -3.348 & 0.005 \\
\hline Mesozoo & 0.273 & 0.056 & 4.871 & $<0.001$ & 0.646 & 0.142 & 3.369 & $<0.001$ \\
\hline SST & - & - & - & - & -0.749 & 0.261 & -3.004 & 0.005 \\
\hline Rhône runoff & 0.306 & 0.109 & 2.903 & 0.006 & - & - & - & - \\
\hline WeMO & - & - & - & - & 0.601 & 0.226 & 2.921 & 0.007 \\
\hline Chl a & - & - & - & - & - & - & - & - \\
\hline Nanophyto & - & - & - & - & - & - & - & - \\
\hline Diat & - & - & - & - & 0.396 & 0.112 & 3.620 & $<0.001$ \\
\hline Nanozoo & - & - & - & - & - & - & - & - \\
\hline Microzoo & - & - & - & - & - & - & - & - \\
\hline
\end{tabular}

thus its condition improves) during summer because spawning does not occur during that season. The progressive decline in food quantity at the end of summer (Lefevre et al. 1997) results a reduction in condition for both species. The seasonal difference in body condition is thus stronger for sardines (which alternate a season of high intake and low expenses [summer], with a season of low intake and high expenses [winter]), than for anchovies (which alternate high intake and expenses with low intake and expenses). As a result, the decrease in condition is more drastic in sardines, and one can wonder if a delayed increase in food abundance might affect sardines to the point of impairing their survival. We hypothesized that after February (in both the 1970s and recent decades), sardines were able to recover their fat reserves as they stopped lipid allocation to the gonads (Lefevre et al. 1997). However, we highlighted differences for sardine between periods (we also investigated another methodology using 2 different length-weight relationships, one per period; direct comparison between their parameters gave similar conclusions to that of the comparison of body condition based on a single length-weight relationship for both periods [data not shown]). First, the condition of this species was always higher in the 1970s (excluding April). Secondly, while their maximal condition occurred in autumn during the first period, it occurred at the beginning of summer in recent years. As the breeding season is likely to be the same over time (Lee 1961, Palomera et al. 2007), this suggests a potential change in foraging conditions. In particular, a change in the phenology of primary and secondary production (usually marked by a second bloom of phytoplankton in September in the Gulf of Lions; Lefevre et al. 1997) might explain the change in small pelagic fish condition.

\section{Fish condition and endogenous characteristics}

For the 2 species, different clusters of condition values were clearly separated in accordance with the general pattern of condition variability previously found (Van Beveren et al. 2014), highlighting the poor condition of anchovy and sardine since 2008.

Another study in the same area pointed out differences in condition between sexes for demersal species such as Mullus barbatus and Pagellus erythrinus (Lloret et al. 2002). However, no difference between the sexes was found in our study nor in a previous study on lipid content (Pethybridge et al. 2014). Thus, for anchovy and sardine of the Gulf of Lions, variations in condition are not due to sex differences.

Significant variations between age classes depended on years. Sardine condition always improved in a similar manner from age- 0 to age- 1 , and either continued to improve (years of good condition), remained steady (years of average condition) or dramatically deteriorated (years of poor condition). These results might provide some explanation about the current changes in size and age structure of sardine, with the recent dominance of small and young individuals in the Gulf of Lions (Van Beveren et al. 2014). Sardine condition deteriorated after July, possibly due of a lack of food followed by the start of the breeding season, which mobilizes a high quantity of lipid reserves. The lack of sufficient fat reserves for 
old sardines could lead to higher mortality for that age class at the end of the winter. Although anchovy also exhibited a pattern whereby condition changed with age and according to groups of years, the trend was not as pronounced. This could be due to both a smaller number of age classes and a lower parameter variability than sardine due to the precision of measurements (i.e. to the nearest $\mathrm{mm}_{i}$ Brosset et al. 2015). Moreover, a shift in quantity and/or availability of zooplankton prey species between years could have affected the condition of older and larger adults.

\section{Fish condition and environmental parameters}

The relationship between fish condition and environmental data was investigated from 2002 to 2011, a period for which environmental data were available and which encompassed years of both good and poor condition for anchovy and sardine. Good sardine condition was linked with high WeMO values, corresponding with low temperature and strong Rhône runoff and wind mixing (i.e. a regime of enhanced primary and secondary productivity). As the statistical model also confirmed the negative effect of temperature on sardine condition, the positive effect of WeMO is likely to be mainly related to planktonic productivity. Variations in SST may affect the fish directly (due to physiological stress) or indirectly (through changes in ecosystem production and prey availability) (Brett 1979, Lloret et al. 2014). Indeed, temperature is a proxy of planktonic productivity. Warmer temperatures can reduce upwelling, and water mixing and may therefore cause the late summer energy peak to occur earlier and at a lower magnitude (Vidussi et al. 2011, Calvo et al. 2011), preventing sardine and anchovy from finding sufficient food resources before entering the prolonged winter season. Moreover, the development of cold-water copepods during the winter could also be affected by warmer water (Halsband-Lenk et al. 2002, Hinder et al. 2014), leading to low copepod abundance as demonstrated in the Balearic Sea (Fernández de Puelles et al. 2004). A similar case has been observed along the Portuguese coast for sardine (Rosa et al. 2010), where temperature explained a sharp decline in their condition as it changed prey availability and phenology during the year. Similarly, anchovy condition was positively affected by the Rhône River outflow. The Rhône is the main source of runoff in the Gulf of Lions (and the Western Mediterranean), and enhances planktonic production by strongly increasing nutrient inputs (Lefevre et al. 1997). Its positive effect can thus be explained as favoring feeding conditions for both species, increasing their energy reserves and improving their condition.

Our results on the significant effect of mesozooplankton support the close relationship between food supply and fish condition. As expected, the mesozooplankton estimated from the coupled model output showed a significant positive relationship with fish condition. This could be explained by the fact that small pelagic fish derive the bulk of their dietary carbon from copepods and euphausiids (Plounevez \& Champalbert 2000, Garrido et al. 2008, Nikolioudakis et al. 2014, Costalago \& Palomera 2014). Sardine condition was also affected by a variation in diatom concentration. The consumption of phytoplankton, and especially diatoms, has previously been documented in the Gulf of Lions (Plounevez \& Champalbert 2000). Furthermore, fish condition is a function of food quality and/or quantity. Food quantity is important, as demonstrated by the decrease in food supply that occurred during invasions of jellyfish, which was in turn associated with a sharp decline in the condition of various species of small pelagic fish (Shulman et al. 2005, Daskalov \& Mamedov 2007, Sabatés et al. 2010). In our study, local (temperature, river runoff, wind mixing and surface chl a) and regional (WeMO) environmental conditions could have a similar impact on the trophic web and thus on fish condition. Additionally, prey quality in terms of species composition can also have an important effect on fish condition. For example, differences in the lipid content of fish varied according to copepod diversity in other sardine populations (Garrido et al. 2008) as well as in populations of capelin (Orlova et al. 2010) in the Atlantic Ocean. In the case of the Gulf of Lions, there is currently insufficient knowledge regarding potential variations in planktonic communities to be able to establish a clear link with the observed changes in fish condition. However, several authors have highlighted changes in the composition and phenology of zooplankton associated with environmental fluctuations in Mediterranean areas surrounding the Gulf of Lions, especially the Ligurian and the Balearic Sea (see Molinero et al. 2005, 2008, Fernández de Puelles \& Molinero 2008, Calvo et al. 2011, Auger et al. 2014). The overall trend in the Northwestern Mediterranean Sea is characterized by increasing temperature, decreasing wind stress and water mixing (Calvo et al. 2011). Such changes induce a longer stratification period, which leads to a reduced nutrient supply to the upper layers and results in changes in phytoplankton and zooplankton compositions, as demon- 
strated by (Auger et al. 2014) in the Gulf of Lions. In such cases, small-sized phytoplankton should dominate, decreasing diatom concentration, affecting grazing efficiency of copepods, and ultimately copepod size and egg production (Halsband-Lenk et al. 2002, Ianora et al. 2003). As anchovy mainly feed on large copepods, and sardine on large copepods and diatoms, fish condition should benefit more from diatom-based food chains (Lloret et al. 2014) than from the more heterotrophic food chains that occur in summer and early fall (e.g. small-sized phytoplankton composed of flagellates and ciliates). In this way, the prevalence of small copepods may be insufficient to satisfy the entire energetic demands of the fish.

Differences in the annual cycle of sardine condition between 1971-1978 and 1993-2013 also support possible changes in environmental conditions. A change in the phenology of primary and secondary production, usually marked by a second bloom of phytoplankton in September in the Gulf of Lions (Lefevre et al. 1997), might explain the observed changes in sardine condition. Using satellite images, Bosc et al. (2004) documented changes in the timing and magnitude of blooms in the Northwestern Mediterranean. In particular, they revealed the quasi-absence of an autumnal bloom in the SeaWIFS images of 1998 to 2001, whereas it was clearly evident in the CZCS images of 1978 to 1986. Bosc et al. (2004) ascribed these differences to environmental changes. Warmer water during the period of 1993 to 2013 could have reducee or delayed the second bloom of phyto- and zooplankton, and prevented sardine from attaining good condition until September or October. This strong dependency of condition on mesozooplankton may be the explanation for the observed shift in phenology of the sardine condition between the 2 periods (1971 to 1978 vs. 1993 to 2011). However, the lack of historical data on chl $a$ and plankton composition for the period 1971 to 1978 prevented us from comparing with current seasonal signals of plankton production. Further research is needed in the Gulf of Lions to investigate the evolution of the planktonic community and to evaluate the link between the different mesozooplankton components and fish condition.

\section{CONCLUSIONS}

This long-term study allowed us to assess the main drivers of condition in 2 small pelagic fish in the Gulf of Lions. Our results are in agreement with previous studies, which highlighted the importance of bottom-up processes for anchovy and sar- dine condition (Shulman et al. 2005, Rosa et al. 2010, Nikolioudakis et al. 2012). Sardine clearly exhibited differences in condition between groups of years, with decreasing and very low $K_{\mathrm{n}}$ values for individuals $2 \mathrm{yr}$ old or older during the poor condition years of 1993, 1996, 2003 and 2008 to 2013. Differences were less evident for anchovy, which showed only small dissimilarities between age classes for the different groups of years. Thus, the poor condition of older individuals (mainly sardine) remains one of the main hypotheses for the current disappearance of old individuals in the Gulf of Lions. Environmental factors, such as temperature and Rhône runoff, were essential to explain small pelagic fish condition, probably through their indirect impact on primary production and thus on food availability. Furthermore, mesozooplankton was the major parameter driving significant fluctuations in condition for both species, and there was a positive effect of diatom concentration on sardine. Therefore, mesozooplankton appears to be an essential aspect of small pelagic fish condition, and further research is required in order to more precisely investigate the impact of this plankton component on fish condition. The recent increase in sprat abundance and biomass (Van Beveren et al. 2014) may have led to an increase in trophic competition, which would also need to be investigated in order to completely understand the current and prolonged poor condition of anchovy and sardine.

Acknowledgements. The authors are grateful to the captain and the crew of RV 'L'Europe', as well as all the scientists on board for their assistance during PELMED (PELagiques en MEDiterranée) surveys. PELMED surveys are co-funded by Europe through the Data Collection Framework. We especially thank all other fishing crews who contributed to the collection of samples at sea. We thank the 2 anonymous reviewers for their careful review of the manuscript and their excellent suggestions. This research was partly supported through the EcoPelGol project (Study of the Pelagic ecosystem in the Gulf of Lions), funded by France Filière Pêche (FFP). The authors are very grateful to Joan Albert López-Bustins for WeMO data. P.B. acknowledges doctoral fellowship support from the French Ministère de l'Education Nationale, de la Recherche et de la Technologie.

\section{LITERATURE CITED}

Adams SM (1999) Ecological role of lipids in the health and success of fish populations. In: Arts MT, Wainman BC (eds) Lipids in freshwater ecosystems. Springer, New York, NY, p 132-160

Auger PA, Diaz F, Ulses C, Estournel C and others (2011) Functioning of the planktonic ecosystem on the Gulf of Lions shelf (NW Mediterranean) during spring and its 
impact on the carbon deposition: a field data and 3-D modelling combined approach. Biogeosciences 8: 3231-3261

- Auger PA, Ulses C, Estournel C, Stemmann L, Somot S, Diaz F (2014) Interannual control of plankton communities by deep winter mixing and prey/predator interactions in the NW Mediterranean: results from a 30-year 3D modeling study. Prog Oceanogr 124:12-27

Baklouti M, Diaz F, Pinazo C, Faure V, Quéguiner B (2006a) Investigation of mechanistic formulations depicting phytoplankton dynamics for models of marine pelagic ecosystems and description of a new model. Prog Oceanogr 71:1-33

Baklouti M, Faure V, Pawlowski L, Sciandra A (2006b) Investigation and sensitivity analysis of a mechanistic phytoplankton model implemented in a new modular numerical tool (Eco3M) dedicated to biogeochemical modelling. Prog Oceanogr 71:34-58

Bakun A (1996) Patterns in the ocean: ocean processes and marine population dynamics. University of California Sea Grant, San Diego, CA, in cooperation with Centro de Investigaciones Biologicas del Noroeste, La Paz

Bănaru D, Mellon-Duval C, Roos D, Bigot JL and others (2013) Trophic structure in the Gulf of Lions marine ecosystem (north-western Mediterranean Sea) and fishing impacts. J Mar Syst 111-112:45-68

Barton BA, Morgan JD, Vijayan MM (2002) Physiological and condition-related indicators of environmental stress in fish. In: Adams SM (ed) Biological indicators of aquatic ecosystem stress. American Fisheries Society, Bethesda, MD, p 111-148

Basilone G, Guisande C, Patti B, Mazzola S and others (2006) Effect of habitat conditions on reproduction of the European anchovy (Engraulis encrasicolus) in the Strait of Sicily. Fish Oceanogr 15:271-280

Blackwell BG, Brown ML, Willis DW (2000) Relative weight $\left(W_{\mathrm{r}}\right)$ status and current use in fisheries assessment and management. Rev Fish Sci 8:1-44

Bolger T, Connolly PL (1989) The selection of suitable indices for the measurement and analysis of fish condition. J Fish Biol 34:171-182

Bosc E, Bricaud A, Antoine D (2004) Seasonal and interannual variability in algal biomass and primary production in the Mediterranean Sea, as derived from 4 years of SeaWiFS observations. Glob Biogeochem Cycles 18: GB1005, doi:10.1029/2003GB002034

Breiman L, Friedman JH, Olshen RA, Stone CJ (1984) Classification and regression trees. Chapman \& Hall, London

Brett JR (1979) Environmental factors and growth. In: Hoar WS, Randall DJ, Brett JR (eds) Fish physiology, Vol 8: bioenergetics and growth. Academic Press, New York, NY, p 599-675

> Brosset P, Fromentin JM, Ménard F, Pernet F and others (2015) Measurement and analysis of small pelagic fish condition: a suitable method for rapid evaluation in the field. J Exp Mar Biol Ecol 462:90-97

Calvo E, Simó R, Coma R, Ribes M and others (2011) Effects of climate change on Mediterranean marine ecosystems: the case of the Catalan Sea. Clim Res 50:1-29

> Costalago D, Palomera I (2014) Feeding of European pilchard (Sardina pilchardus) in the northwestern Mediterranean: from late larvae to adults. Sci Mar 78:41-54

Cury P, Bakun A, Crawford RJM, Jarre A, Quiñones RA, Shannon LJ, Verheye HM (2000) Small pelagics in upwelling systems: patterns of interaction and structural changes in 'wasp-waist' ecosystems. ICES J Mar Sci 57: 603-618

- Darnaude AM, Salen-Picard C, Polunin NVC, HarmelinVivien ML (2004) Trophodynamic linkage between river runoff and coastal fishery yield elucidated by stable isotope data in the Gulf of Lions (NW Mediterranean). Oecologia 138:325-332

> Daskalov GM, Mamedov EV (2007) Integrated fisheries assessment and possible causes for the collapse of anchovy kilka in the Caspian Sea. ICES J Mar Sci 64: 503-511

> Fernández de Puelles MLF, Molinero JC (2008) Decadal changes in hydrographic and ecological time-series in the Balearic Sea (western Mediterranean), identifying links between climate and zooplankton. ICES J Mar Sci 65:311-317

Fernández de Puelles MLF, Valencia J, Vicente L (2004) Zooplankton variability and climatic anomalies from 1994 to 2001 in the Balearic Sea (Western Mediterranean). ICES J Mar Sci 61:492-500

Ferrer-Maza D, Lloret J, Muñoz M, Faliex E, Vila S, Sasal P (2014) Parasitism, condition and reproduction of the European hake (Merluccius merluccius) in the northwestern Mediterranean Sea. ICES J Mar Sci J Cons 71: 1088-1099

Ferrer-Maza D, Muñoz M, Lloret J, Faliex E, Vila S, Sasal P (2015) Health and reproduction of red mullet, Mullus barbatus, in the western Mediterranean Sea. Hydrobiologia 753:189-204

Froese R (2006) Cube law, condition factor and weightlength relationships: history, meta-analysis and recommendations. J Appl Ichthyology 22:241-253

Ganias K, Somarakis S, Koutsikopoulos C, Machias A (2007) Factors affecting the spawning period of sardine in two highly oligotrophic seas. Mar Biol 151:1559-1569

Garrido S, Ben-Hamadou R, Oliveira PB, Cunha ME, Chícharo MA, van der Lingen CD (2008) Diet and feeding intensity of sardine Sardina pilchardus: correlation with satellite-derived chlorophyll data. Mar Ecol Prog Ser 354:245-256

GFCM (General Fisheries Commission for the Mediterranean) (2012) Report of the working group on stock assessment of small pelagic species. Scientific Advisory Committee and Sub-committee on Stock Assessment, FAO, Rome

> Halsband-Lenk C, Hirche HJ, Carlotti F (2002) Temperature impact on reproduction and development of congener copepod populations. J Exp Mar Biol Ecol 271:121-153

Heino M, Godø OR (2002) Fisheries-induced selection pressures in the context of sustainable fisheries. Bull Mar Sci 70:639-656

> Herrmann MJ, Somot S (2008) Relevance of ERA40 dynamical downscaling for modeling deep convection in the Mediterranean Sea. Geophys Res Lett 35:L04607, doi: 10.1029/2007GL032442

> Herrmann M, Sevault F, Beuvier J, Somot S (2010) What induced the exceptional 2005 convection event in the northwestern Mediterranean basin? Answers from a modeling study. J Geophys Res 115:C12051, doi: 10.1029/2010JC006162

> Herrmann M, Diaz F, Estournel C, Marsaleix P, Ulses C (2013) Impact of atmospheric and oceanic interannual variability on the Northwestern Mediterranean Sea pelagic planktonic ecosystem and associated carbon cycle. J Geophys Res Oceans 118:5792-5813 
Hinder SL, Gravenor MB, Edwards M, Ostle C and others (2014) Multi-decadal range changes vs. thermal adaptation for north east Atlantic oceanic copepods in the face of climate change. Glob Change Biol 20:140-146

> Hurvich CM, Tsai CL (1989) Regression and time series model selection in small samples. Biometrika 76:297-307

> Ianora A, Poulet SA, Miralto A (2003) The effects of diatoms on copepod reproduction: a review. Phycologia 42: 351-363

ICES (2008) Report of the workshop on small pelagics (Sardina pilchardus, Engraulis encrasicolus) maturity stages (WKSPMAT). ICES CM 2008/ACOM:40, International Council for the Exploration of the Sea, Denmark

> Jakob EM, Marshall SD, Uetz GW (1996) Estimating fitness: a comparison of body condition indices. Oikos 77:61-67

Lambert Y, Dutil JD (1997) Condition and energy reserves of Atlantic cod (Gadus morhua) during the collapse of the northern Gulf of St. Lawrence stock. Can J Fish Aquat Sci 54:2388-2400

> Le Cren ED (1951) The length-weight relationship and seasonal cycle in gonad weight and condition in the perch (Perca fluviatilis). J Anim Ecol 20:201-219

Lee JY (1961) La sardine du golfe du lion (Sardina pilchardus sardina Regan). Rev Trav Inst Pech Marit 25: 417-513

> Lefevre D, Minas HJ, Minas M, Robinson C, Williams B, Le PJ, Woodward EMS (1997) Review of gross community production, primary production, net community production and dark community respiration in the Gulf of Lions. Deep-Sea Res II 44:801-832

> Lloret J, de Sola LG, Souplet A, Galzin R (2002) Effects of large-scale habitat variability on condition of demersal exploited fish in the north-western Mediterranean. ICES J Mar Sci 59:1215-1227

Lloret J, Shulman G, Love RM (2014) Condition and health indicators of exploited marine fishes. John Wiley \& Sons, Hoboken, NJ

> Malzahn A, Aberle N, Clemmesen C, Boersma M (2007) Nutrient limitation of primary producers affects planktivorous fish condition. Limnol Oceanogr 52:2062-2071

> Marsaleix P, Auclair F, Estournel C (2009) Low-order pressure gradient schemes in sigma coordinate models: the seamount test revisited. Ocean Model 30:169-177

Marsaleix P, Auclair F, Estournel C, Nguyen C, Ulses C (2011) An accurate implementation of the compressibility terms in the equation of state in a low order pressure gradient scheme for sigma coordinate ocean models. Ocean Model 40:1-13

Marsaleix P, Auclair F, Duhaut T, Estournel C, Nguyen C, Ulses C (2012) Alternatives to the Robert-Asselin filter. Ocean Model 41:53-66

Martin-Vide J, Lopez-Bustins JA (2006) The Western Mediterranean Oscillation and rainfall in the Iberian Peninsula. Int J Climatol 26:1455-1475

McBride RS, Somarakis S, Fitzhugh GR, Albert A and others (2015) Energy acquisition and allocation to egg production in relation to fish reproductive strategies. Fish Fish 16:23-57

McPherson LR, Slotte A, Kvamme C, Meier S, Marshall CT (2011) Inconsistencies in measurement of fish condition: a comparison of four indices of fat reserves for Atlantic herring (Clupea harengus). ICES J Mar Sci 68:52-60

> Mendes B, Fonseca P, Campos A (2004) Weight-length relationships for 46 fish species of the Portuguese west coast. J Appl Ichthyology 20:355-361
Millar JS, Hickling GJ (1990) Fasting endurance and the evolution of mammalian body size. Funct Ecol 4:5-12

Millot C (1990) The Gulf of Lions' hydrodynamics. Cont Shelf Res 10:885-894

Molinero JC, Ibanez F, Nival P, Buecher E, Souissi S (2005) North Atlantic climate and northwestern Mediterranean plankton variability. Limnol Oceanogr 50:1213-1220

Molinero JC, Ibanez F, Souissi S, Buecher E, Dallot S, Nival $P$ (2008) Climate control on the long-term anomalous changes of zooplankton communities in the Northwestern Mediterranean. Glob Change Biol 14:11-26

> Morgan MJ (2004) The relationship between fish condition and the probability of being mature in American plaice (Hippoglossoides platessoides). ICES J Mar Sci 61:64-70

> Murphy BR, Brown ML, Springer TA (1990) Evaluation of the relative weight $\left(W_{\mathrm{r}}\right)$ index, with new applications to walleye. N Am J Fish Manage 10:85-97

> Ndjaula HON, Gerow KG, van der Lingen CD, Moloney CL, Jarre A (2013) Establishing a baseline for evaluating changes in body condition and population dynamics of sardine (Sardinops sagax) in the southern Benguela ecosystem. Fish Res 147:253-263

Nikolioudakis N, Isari S, Pitta P, Somarakis S (2012) Diet of sardine Sardina pilchardus: an 'end-to-end' field study. Mar Ecol Prog Ser 453:173-188

Nikolioudakis N, Isari S, Somarakis S (2014) Trophodynamics of anchovy in a non-upwelling system: direct comparison with sardine. Mar Ecol Prog Ser 500:215-229

Orlova E, Rudneva G, Renaud P, Eiane K, Savinov V, Yurko A (2010) Climate impacts on feeding and condition of capelin Mallotus villosus in the Barents Sea: evidence and mechanisms from a 30 year data set. Aquat Biol 10: $105-118$

> Óskarsson GJ, Kjesbu OS, Slotte A (2002) Predictions of realised fecundity and spawning time in Norwegian spring-spawning herring (Clupea harengus). J Sea Res 48:59-79

> Palomera I, Olivar MP, Salat J, Sabatés A, Coll M, García A, Morales-Nin B (2007) Small pelagic fish in the NW Mediterranean Sea: an ecological review. Prog Oceanogr 74: 377-396

Pethybridge H, Bodin N, Arsenault-Pernet EJ, Bourdeix JH and others (2014) Temporal and inter-specific variations in forage fish feeding conditions in the NW Mediterranean: lipid content and fatty acid compositional changes. Mar Ecol Prog Ser 512:39-54

> Plounevez S, Champalbert G (2000) Diet, feeding behaviour and trophic activity of the anchovy (Engraulis encrasicolus, L.) in the Gulf of Lions (Mediterranean Sea). Oceanol Acta 23:175-192

> Porath MT, Peters EJ (1997) Use of walleye relative weights $\left(W_{\mathrm{r}}\right)$ to assess prey availability. N Am J Fish Manage 17: $628-637$

R Core Team (2013). R: A language and environment for statistical computing. R Foundation for Statistical Computing, Vienna. www.R-project.org

Rosa R, Gonzalez L, Broitman BR, Garrido S, Santos AMP, Nunes ML (2010) Bioenergetics of small pelagic fishes in upwelling systems: relationship between fish condition, coastal ecosystem dynamics and fisheries. Mar Ecol Prog Ser 410:205-218

Sabatés A, Pagès F, Atienza D, Fuentes V, Purcell JE, Gili JM (2010) Planktonic cnidarian distribution and feeding of Pelagia noctiluca in the NW Mediterranean Sea. Hydrobiologia 645:153-165 
Schamber JL, Esler D, Flint PL (2009) Evaluating the validity of using unverified indices of body condition. J Avian Biol 40:49-56

Schulte-Hostedde AI, Millar JS, Hickling GJ (2001) Evaluating body condition in small mammals. Can J Zool 79: 1021-1029

Schulte-Hostedde AI, Zinner B, Millar JS, Hickling GJ (2005) Restitution of mass-size residuals: validating body condition indices. Ecology 86:155-163

Shulman GE, Love RM (1999) The biochemical ecology of marine fishes. In: Southward AJ, Tyler PA, Young CM (eds) Advances in marine biology, Vol 36. Academic Press, London, p 205-213

Shulman GE, Nikolsky VN, Yuneva TV, Shchepkin GSMY and others (2005) Fat content in Black Sea sprat as an indicator of fish food supply and ecosystem condition. Mar Ecol Prog Ser 293:201-212

Simat V, Bogdanovi T (2012) Seasonal changes in proximate composition of anchovy (Engraulis encrasicolus, L.) from the central Adriatic. Acta Adriat 53:125-131

Sinovčić G, Keč VČ, Zorica B (2008) Population structure, size at maturity and condition of sardine, Sardina pilchardus (Walb., 1792), in the nursery ground of the eastern Adriatic Sea (Krka River Estuary, Croatia). Estuar Coast Shelf Sci 76:739-744

Stevenson RD, Woods WA (2006) Condition indices for con-

Editorial responsibility: Stylianos Somarakis, Heraklion, Greece servation: new uses for evolving tools. Integr Comp Biol 46:1169-1190

Van Beveren E, Bonhommeau S, Fromentin JM, Bigot JL and others (2014) Rapid changes in growth, condition, size and age of small pelagic fish in the Mediterranean. Mar Biol 161:1809-1822

> Vidussi F, Mostajir B, Fouilland E, Le Floc'h E and others (2011) Effects of experimental warming and increased ultraviolet $\mathrm{B}$ radiation on the Mediterranean plankton food web. Limnol Oceanogr 56:206-218

Villegas-Hernández H, Lloret J, Muñoz M (2015) Reproduction, condition and abundance of the Mediterranean bluefish (Pomatomus saltatrix) in the context of sea warming. Fish Oceanogr 24:42-56

Wilson AJ, Nussey DH (2010) What is individual quality? An evolutionary perspective. Trends Ecol Evol 25:207-214

> Winters GH, Wheeler JP (1994) Length-specific weight as a measure of growth success of adult Atlantic herring ( $\mathrm{Clu}$ pea harengus). Can J Fish Aquat Sci 51:1169-1179

> Zlatanos S, Laskaridis K (2007) Seasonal variation in the fatty acid composition of 3 Mediterranean fishsardine (Sardina pilchardus), anchovy (Engraulis encrasicolus) and picarel (Spicara smaris). Food Chem 103: 725-728

Zuur AF, Ieno EN, Smith GM (2007) Analysing ecological data. Springer, New York, NY

Submitted: October 10, 2014; Accepted: March 10, 2015 Proofs received from author(s): May 22, 2015 